\title{
Humanity's exemplary justice: from hostis to hostia humani generis
}

\author{
EDWIN BIKUNDO
}

As a term, 'crimes against humanity' is on the face of it eternally open to signifying too much. Even when championing the ethical treatment of animals, for instance, nobody deploys terms such as crimes against the bovine for cows, or the canine for dogs, or the equine for horses or the feline for cats, etc. but instead universally call for their 'humane' treatment. This is because all crimes are in the literal sense against humanity (just as all lawyers are in the same sense human rights lawyers despite appeals to the divine and other abstractions). It takes human beings to legislate the law, breach it, and try and then punish the perpetrators even when the offence has an animal subject. This is why to call for the humane treatment of humans is the highest point of self-reflexivity, making crimes against humanity the most self-reflexive criminal category where we reflect on the human qua human: a category hor concours, as Harmen van der Wilt argues earlier in this volume, because it attacks humanity itself and in that way affects and invokes the entire international community. Van der Wilt also points out the necessary connection between bioethics and international criminal law. Indeed, there is solid textual backing of this in the Geneva Conventions and their additional protocols. $^{91}$

According to Daniel Heller-Roazen, humanity is a recent entrant to the legal lexicon. ${ }^{92}$ Indeed, for Roman legal scholars, homo 'human being'

I acknowledge gratefully the helpfully critical comments on earlier drafts of this article by Peter Rush, Philip Stenning, Wouter Werner and Immi Tallgren.

91 For examples of breaches of bioethics as grave breaches of international humanitarian law and international criminal law, see Geneva Convention I, Articles 12 and 50; Geneva Convention II, Articles 12 and 51; Geneva Convention III, Articles 13 and 130; Geneva Convention IV, Articles 32 and 147; Additional Protocol I, Articles 11 and 85 and Additional Protocol II, Article 5.

92 Daniel Heller-Roazen, The Enemy of All: Piracy and the Law of Nations (New York: Zone Books, 2009), 147. 
was in contradistinction to persona 'person'. Mere humanity did not refer to positive rights or their ground. It was in principle excluded from legal considerations. Indeed, what became 'crimes against humanity' were first characterised as 'crimes against Christianity'. Nuremberg Charter, the court was able to have unprecedented jurisdic. tion over the unprecedented crimes committed against German Jews by their own government. ${ }^{94}$

Larry May's conception of crimes against humanity is probably the most well known. It describes protective and security principles as underlying the international jurisdiction over the crimes. May's approach, however, does not really take into account the normative and descriptive elements of the law where 'humanity' has both qualitative and quantitative elements. Christopher Macleod, ${ }^{95}$ for one, identifies a certain ambiguity of the term 'humanity', which can refer either to a species or to the quality of being humane, i.e. humaneness. ${ }^{96}$ Macleod helpfully reviews eight different conceptions of crimes against humanity in the relevant literature. In the end, he favours a definition where 'an action is a crime against humanity if and only if it is a crime that damages humankind ${ }^{\prime}{ }^{97}$ very literally, an offence committed against humanity as such. 98 . This comes at some cost, though, because the author readily admits to making humanity a metaphysical object. ${ }^{99}$ How it makes the transition from the metaphysical to the physical is the subject of this chapter. The chapter examines the divergence and convergence of the theory and practice of international criminal justice in order to provide a factual, textual, and legal background that sketches out its redemptive sacrificial economy. Synthesising some common themes encountered in the subject area (including global politics, exemplary trials, communityformation via exclusion and inclusion, secular and religious mystification, symbolism, and perpetual promise), this chapter's thesis is that international criminal law processes embody the international community through iconic presentation. The phrase hostis humani generis or enemy of all mankind has been identified as being at the very beginning of international criminal law. Luigi Corrias observes that merely by virtue of invoking crimes against humanity its perpetrators are designated hostes humani generi. Dan Edelstein, taking a philological approach,

93 Ibid., $158 \quad 94$ Ibid., 159.

95 Christopher Macleod, 'Towards a Philosophical Account of Crimes against Humanity', European Journal of International Law 21.2 (2010): 283.

96 Ibid. $\quad{ }^{97}$ Ibid., $287 . \quad 98$ Ibid. $\quad{ }^{99}$ Ibid., 295. 
traces the phrase's various guises and transmutations from its origins in classical antiquity, through to early Christianity, the French Revolution to late politics and law. ${ }^{100}$ The phrase has been used to describe not just pirates but everything from the devil to tyrants, and even kings. Essentially its purpose is twofold: first, to provide jurisdiction where there would otherwise be none, and, second,' it occasionally serves to dehumanise anyone to whom the epithet is applied. According to Giorgio Agamben, the gesture of sacrifice presents a theurgical aspect, in that humans act ritually on the gods in order effectively to create them. ${ }^{101}$ For Giorgio Agamben, sacrifice provides a mythical foundation for society rather than the fact of mere action without any actual grounding. ${ }^{102}$ It supplies the fiction of a beginning for a community, which beginning by a simultaneous exclusion and inclusion excludes what, in reality, is the entire foundation of communal life. ${ }^{103}$ This chapter's core argument is therefore that a counterpart phrase hostia humani generis or sacrifice for all mankind would have explanatory value indicating as it does that those accused of crimes against humanity are also tried for and on behalf of redeeming all of humanity.

As van der Wilt notes, from the perspective of international criminal law there is no fundamental disagreement with disciplines like bioethics as to the conceptual content of humanity. In the introduction, Britta van Beers, Luigi Corrias and Wouter Werner point out how biolaw traces its birth from medical-ethical concepts developed during the trial of Nazi physicians and researchers. International criminal justice is here portrayed as a legal-political apparatus for not just generating justice and protection for humanity but also fostering humaneness.

International criminal law's contribution to this anthropological machine is the constant generation of social scapegoats through a sacrificial economy. The chapter stages an engagement between international criminal law and an innovative theoretical framework, essentially sketching out an iconography of the criminal trial as being dependent upon a sacrificial economy.

Dan Edelstein, 'Hostis Humani Generis: Devils, Natural Rights and Terror in the French Revolution', Telos 141 (2007): 57.

101 Giorgio Agamben, The Kingdom and the Glory: For a Theological Genealogy of Economy and Government (Stanford University Press, 2011), 226.

${ }^{102}$ Alex Murray and Jessica Whyte, The Agamben Dictionary (Edinburgh University Press, 2011), 173.

103 Giorgio Agamben, Language and Death: The Place of Negativity (Minneapolis, Minn.: University of Minnesota Press, 1991), 105. 


\section{Individual criminal responsibility for mass political violence}

There is always, it seems, something new from Africa in the International Criminal Court's (ICC) case docket. As of this writing, that Court has five situations and cases from Uganda, Sudan, the Democratic Republic of Congo, the Central African Republic, Kenya, Libya and Côte d'Ivoire. ${ }^{104}$ All these in a court that was set up, it is said, to punish those most responsible for 'the most serious crimes of concern to the international community as a whole' that 'deeply shock the conscience of humanity'. ${ }^{105}$ Faced with this rhetorical claim, surely the proper scholarly attitude then can only be an inquisitively open-minded scepticism towards Africans having a near monopoly of these crimes and prescribing select criminal trials as being the panacea. This chapter casts a critical eye at two apparently unrelated fields of inquiry, both addressing an ethical gap between the theory and the practice of international criminal justice. The first regards a certain ethical ambivalence about whether a criminal trial relying on individual criminal responsibility can prevent the recurrence of mass violence. The second highlights the ethical ambiguity of how a universal court, designed and intended to prosecute those most responsible for the worst crimes known to humanity, only has cases from a single continent whether by coincidence or not. The problematic link between those otherwise unrelated questions in the context of international criminal justice is the continent and peoples of Africa. In theory, at least as per the rhetoric of the then UN Secretary-General Kofi Annan, the establishment of the ICC in 1998 was a historical moment gifting hope to future generations, and a great step towards universalising human rights and the rule of law. ${ }^{106}$ Annan, quoting Marcus Tullius Cicero's declaration that 'in the midst of arms, law stands mute' (inter armes silent leges), said that there was now real hope that Cicero's cynicism would be less justifiable in the future than it had been in the past. ${ }^{107}$ According to Annan, until the moment establishing the ICC,

104 ICC, Situations and Cases, 2011, available at www.icc-cpi.int/en_menus/icc/situations\% 20and\%20cases/Pages/situations\%20and\%20cases.aspx (accessed 14 August 2013).

105 Rome Statute of the International Criminal Court 1998, Preamble and Article 1 (hereafter, Rome Statute).

106 ICC, press release L/2890, "Secretary-General Says Establishment of International Criminal Court Is Major Step in March towards Universal Human Rights, Rule Of Law', 1998, available at www.un.org/News/Press/docs/1998/19980720.12890.html (accessed 14 August 2013).

107 lbid. 
when powerful men committed crimes against humanity, they had known 'that as long as they remained powerful no earthly court could judge them'. Indeed, even when they were judged here on earth (as happened in 1945) they could protest that it was merely a form of vengeance: 'victors' justice'. Consequently, the accused could explain their guilt away by claiming their prosecution was really a persecution only occasioned by others who proved more powerful than they and those more powerful were in that way able to sit in judgment. At the same momentous occasion, Philippe Kirsch, the chairman of the diplomatic conference setting up the court and later a president of the ICC, concurred that setting up the court had established solid foundations of an institution that would have a major impact for future generations. According to Kirsch, the international community had acted to show that it would not stand silently by as genocide was committed. The adoption of the Statute furthermore was 'really the future of humanity in many ways' ${ }^{108}$ The central question structuring this piece is how do representative trials of persons accused of having the greatest responsibility for the most serious crimes of concern to the international community as a whole supposedly bind recurrent violence?

The universality and promise of international criminal justice

Arguably, universal justice has tensions within and between justice and universality. The opposition within justice regards simultaneously addressing individual criminal responsibility and mass violence that implicates a substantial segment of a population. The contradiction within universality is how a court set up by the international community with the potential to cover all states, whether members of the Rome Statute or not, only has African cases even after utilising all the various means by which it may be seized of jurisdiction. This is in the context of its only being able to act where the state that would otherwise do so is either unable or unwilling to perform its prosecutorial duty. ${ }^{109}$

\section{Community-formation and secular mystification}

Sarah Nouwen and Wouter Werner have argued and demonstrated empirically that international criminal trials are an irreducibly political 
process. ${ }^{110}$ Marti Koskenniemi says that the symbolism of the international criminal trial enables the formation of a moral community. ${ }^{111}$ Koskenniemi also says that international law, although secular, has a horizon of transcendence couched in messianic language, whose present imperfections only set off its yet-to-be fulfilled promises the brighter. ${ }^{112}$ Immi Tallgren points out that international criminal justice, following the rhetoric of domestic criminal justice, sees all criminals (whether robbers or genocidaires) as having a single disease whose cure is deterrent punishment. ${ }^{13}$ Given such rhetoric, the logic of both domestic and international criminal justice is that achieving general prevention requires 'exemplary decisions'. ${ }^{114}$ This rhetoric and consequent logic are, however, inadequate to serve fully its expressive purpose, which is the prevention of criminality. ${ }^{115}$ International criminal justice in this way attracts attention to itself and therefore away from what it is intended to address. International criminal law is consequently a 'kind of religious service of hope that is stronger than the desire to face everyday life' that enables the avoidance of the why question in international criminal law. ${ }^{116}$ To put it baldly, international criminal law enables global governance by simultaneously rationalising and mystifying political control. ${ }^{117}$

Taking a cue from Koskenniemi, Nouwen, Werner, Simpson and one of their common interlocutors, Carl Schmitt, who stated that all 'significant concepts of the modern theory of the state' are secularised theological concepts because of their 'historical development' and 'systematic structure', 118 I argue that the iconographic symbolism of a few representative trials in the Hague, an iconic city ('the legal capital of the world'), to prevent mass organised political violence, may be both irreducibly political and irreducibly theological. This argument demonstrates that unpacking the iconography of international criminal justice reveals that iconic trials in an iconic city by an iconic prosecutor have their own

110 Sarah Nouwen and Wouter Werner, 'Doing Justice to the Political: The International Criminal Court in Uganda and Sudan', European Journal of International Law 21.4 (2011). $941-96$.

11. M. Koskenniemi, 'Between Impunity and Show Trials', Max Planck Yearbook of United Nations Law 6.1 (2002): 1-32.

112 M. Koskenniemi, International Law as Political Theology: How to Read Nomos der Erde? Constellations 11.4 (2004): 507.

13. Immi Tallonen, 'The Sensibility and Sense of International Criminal Law', European Joumal of International Law 13.3 (2002): 561-95.

114 1bid. 576 . 115 Ibid., 571-2. ${ }^{116}$ Ibid., 593. ${ }^{117}$ Ibid., 594-5.

118 Carl Schmit, Political Theology: Four Chapters on the Concept of Sovereignty (University of Chicago Press, 2005), 36. 
rhetoric, logic and aesthetic. The rhetoric is organised around achieving universal justice on behalf of the international community/humanity through singular trials of particular individuals. The logic follows an exchange of responsibilities between individuals and their communities via an uncertain and indirect substitution of personal rights for social harmony and order. The aesthetic présents and represents the ICC prosecutor as an image and icon of the international community's justice.

The logic, rhetoric and aesthetic all combine to provide an assemblage of means and methods for the ad hoc realisation of abstract principles, i.e. an economy. This is specifically a sacrificial economy linking contingent means for realising permanent ends. All that is in order to visualise the invisible, and hear the inaudible international community through its icons as embodied representations of something that has its own existence, yet which is only visible and audible through those icons. ${ }^{119}$ The icon sets up a relation between the visible and invisible without any respect for realism or neglect for the material. ${ }^{120}$ The question therefore is not whether the icon is by nature or by definition true or false, or even good or bad, because its truth is derived not from itself but from its founding cause. ${ }^{121}$ The essence of the iconic image is not its visibility (which belongs to imagery and not to iconicity); it is its economy, and that alone, that is visible in its iconicity'. ${ }^{122}$ To belabour the point, the rhetorical, logical and aesthetical substitution of a flesh and blood prosecutor for the immaterial international community is precisely what visualises and renders audible that international community for the purposes of international criminal justice. The ethical position of this, however, falls short of that to which it aspires.

The occurrence of post-electoral violence in Kenya is a case study referred back to repeatedly in this chapter to illustrate different facets of the main argument as they develop. Although it is an example drawn from an African case before the ICC, it has general insights to contribute that are generally applicable to evaluating other courts and tribunals, both historical and contemporary. According to the ICC prosecutor Luis Moreno-Ocampo, the leadership of Kofi Annan was essential for his office. ${ }^{123}$ A practical illustration of the working of the Court pursuant

119 Marie-José Mondzain, Image, Icon, Economy: The Byzantine Origins of the Contempor ary Imaginary, Cultural Memory in the Present (Stanford University Press, 2005), 86.

120 Ibid., 85. 121 Ibid., $82 . \quad 122$ Ibid., 82.

123 ICC, Mr Luis Moreno-Ocampo, Prosecutor of the International Criminal Court, Seven teenth Diplomatic Briefing, Statement, 4 November 2009, available at www.icc-cpilint 
to the theory of universal justice was when Annan, in his capacity as chair of the African Union Panel of Eminent African Personalities, submitted to the ICC prosecutor a sealed envelope containing a list of persons allegedly implicated in post-electoral violence occurring in Kenya. ${ }^{124}$ Annan explained that in Kenya there was no opposition between a truth commission and justice and suggested a three-pronged approach with the ICC prosecuting those most responsible, national accountability proceedings for other perpetrators, as well as reforms and mechanisms such as the Truth, Justice and Reconciliation Commission. 125

Pursuant to this prompting from Annan, the ICC prosecutor subsem quently said more than once that Kenya would be an example to the world/international community on managing and preventing recurrent political violence: ${ }^{126}$

The Prosecutor emphasized that Kenya would prove an example of how to work together with the international community and the Court to end impunity and prevent future crimes. "Kenya will show how to manage past violence and how to create a peaceful process for the upcoming elections in 2012. Kenya will be an example to the world.' ... 'We all agree that impunity is not an option,' he stressed, 'and that to prevent new violence in 2012 it is necessary to prosecute those responsible for the crimes committed during the post election violence. ${ }^{127}$

To be fair, it was the Kenyan government itself that originated the idea in the first place of using international criminal prosecutions to prevent the recurrence of political violence:

Regarding Kenya, I met on 3 July with a Government delegation from Kenya, led by Justice Minister Kilonzo. They informed me that, in order to prevent a recurrence of violence during the next election cycle, those most responsible for the previous post-election violence must be held

NR/rdonlyres/B2000A0D-2159-40E6-A24F-8952FF34D3B4/281 196/OTP_DiplomaticBriefing 04112009.pdf (accessed 11 April 2011).

124. lbid. ${ }^{25}$ Ibid.

126 ICC, ICC Prosecutor: Kenya Can Be an Example to the World', press release ICCOTP-20090918-PR452, 18 September 2009, available at www.icc-cpi.int/en_menus/iccl situations $\% 20$ and $\% 20$ cases/situations/situation $\% 20$ icc\% $200109 /$ press\%20releases/Pages/ pr452.aspx (accessed 14 August 2013); ICC, 'ICC Prosecutor Supports Three-Pronged Approach to Justice in Kenya', ICC press release ICC-OTP-20090930-PR456, 30 SeptemBer 2009, available at www.icc-cpi.int/en_menus/icc/situations $\% 20$ and\%20cases/ situations/situation\%20icc\%200109/press\%20releases/Pages/pr456.aspx (accessed 14. August 2013).

172. ICC Prosecutor: Kenya Can Be an Example to the World'. 
accountable. They are committed to ending impunity, and committed themselves to refer the situation to the Court if efforts to conduct national proceedings fail. $^{128}$

For one thing, preventative exemplification to prevent mass violence is problematic because the law only provides the court with jurisdiction over natural persons who are to be individually responsible and liable for punishment without allowing corporate or group liability. ${ }^{129}$ The selection of accused, however, does seem to be with a view to how they exemplify acts committed en masse and in concert. Indeed, the then prosecutor has assured that the 'persons bearing the greatest responsibility for the most serious crimes are being brought to justice'. ${ }^{130}$ What therefore does the ICC prosecutor mean when he constantly repeats the refrain that the Kenya situation would be an example supposedly to prevent recurring violence. Did the then prosecutor speak literally or literarily? Is peace a cause or an effect of justice? A literal analysis of the trial process would only reveal an individual in jeopardy of his or her own life, liberty or property. This, bar a mysterious link, does not directly translate to communal peace. How does one prosecute their way to peace? Perhaps there is some indirect analogical relation amenable to elucidation.

A literary or figurative analysis by contrast to a literal one could link individual trials to communal peace, precisely through analogy by making an example of the accused to other potential accused. The point is that there is neither empirical proof nor factual analysis relied on or referred to linking peace and criminal trial, only hopes, promises, suppositions, assumptions and, central to this chapter, ritualised conduct. Indeed interlocutors such as the then prosecutor are not concerned with the actual reality of their intended results but only with their meaning in terms of iconicity to the various constituencies of international criminal justice. The then prosecutor and the Kenyans therefore speak of more than merely law and to understand those statements better we need to rely on more than a purely legal analysis of the pacifying preventative exemplar being brought to bear.

The example as a category is used for reasoning analogically by comparing a particular case to a particular case as opposed to either

128 See n. 127, above.

129 Rome Statute, Article 25.

${ }^{130}$ ICC, Resolution ICC-ASP/8/Res.9, adopted at the 10th plenary meeting, 25 March 2010 , by consensus, available at www.icc-cpi.int/iccdocs/asp_docs/Resolutions/ICC-ASP 8 Res.9-ENG.pdf (accessed 11 April 2011). 
deduction (comparing from the universal to the particular) or induction (comparing from the particular to the universal). ${ }^{131}$ The example is a curious case because, while at the same time it belongs to and defines a category, it does so simultaneously as part of and yet outside the same category it defines and to which it belongs. ${ }^{132}$ Because there is no such thing as absolute guilt, insofar as an accused is made an example of by being tried and punished for the future possible actions of others he or she cannot help but be innocent. Yet, at the same time, he or she is guilty for his or her own past conduct making him or her simultaneously belong and not belong wholly to both the categories of innocence and guilt. That innocence, although perhaps miniscule in the scheme of things, is nevertheless critical. According to René Girard, innocence is essential in creating a social scapegoat in order to prevent recurrent vielence because it renders the sacrificial ritual different from vengeance and, in that way, arrests any spiral into endless mutually destructive violence through, for instance, vendettas without end. ${ }^{133}$

\section{Selective universality}

The rhetoric is therefore that humanity sits in judgment over inhumanity. Given the geographic selectivity of the cases, though, it would rather more accurately be put as one segment of humanity sits in judgment over another. One cannot help but detect a note of amphiboly here where Africans are exclusively responsible for all of humanity's very worst problems, such indiscriminating use of universal sets in international criminal law (not just humanity, but closely related terms - the international community and mankind) is under critiqued within the discipline. That lack of sufficient critique is probably because those sets are precisely what make the field itself intelligible and one cannot very well question them and remain comfortably meaningful within the field. These sets moreover are crucial and deployed at strategic moments in discourse.

They are crucial in providing a basis for both galvanising action and paralysing dissent and they are strategic in how they artfully structure the

31. Ciorgio Agamben, The Signature of All Things: On Method (New York and Cambridge: Zone Books, 2009), 19.

132 Giorgio Agamben, Homo Sacer: Sovereign Power and Bare Life (Stanford University Press, 1998), 22; Agamben, The Signature of All Things, 24.

133. Rene Grard, Violence and the Sacred (Baltimore, Md.: Johns Hopkins University Press, 1977), 14 and $22-6$. 
field into insiders and outsiders, while at the same time claiming to act on behalf of both. Moreover, this acting on the behalf of both involves selfselected active insiders acting against more or less passively acquiescent outsiders. The outsider, in terms of humanity, nonetheless remains human and part of humanity. This stands to reason because non-humans could never be guilty of inhumanity. These sets of sets therefore paradoxically include and exclude at the same time insiders and outsiders. The insiders are included as actors but excluded as the acted upon, while the outsiders are excluded as actors but included as the acted upon. Humanity therefore is the set of sets that simultaneously includes and excludes itself. That exclusive-inclusion and inclusive-exclusion dynamic is what makes the international system actually work in the first place, and without it the system is again unintelligible and paralysed. Universality is arguably at present a useful legal fiction that on occasion cloaks injustice. Suppose, for a moment, we entertain the somewhat unusual thought (elaborated below) that a secular sacrificial economy lies at the root of international criminal justice, what would it mean if, as according to Edward Carr, this ethical system were built on the sacrifice of the weaker brother? ${ }^{134}$

Africa is the example par excellence of the outside and Africans are the perennial outsiders. However, following from the argument outlined above, Africa and Africans constitute the international community's boundary as such via international criminal justice. In an empirical sense, Africans are the only ones currently under active investigation and trial at the ICC. This is not because of any deliberate intention of a prosecutor or any vast racial plot but follows through from the structure of a faith-based and piety-dependent criminal justice system where judges are not judged and trials are not tried. The reason why Africa is and shall remain the focus of international criminal law is that the boundary of the set of sets that is and contains humanity is underdeveloped and, in the interim, requires to be conjured up through configuring beings that are simultaneously outside and inside by insiders that are at the same time inside and outside. The beings tried are broadly familiar as sacrificial scapegoats while those doing the trying are familiar as sovereigns. A very specific form of scapegoating is done in international criminal law. The accused are supposed to bear the highest

134 Edward H. Carr and Michael Cox, The Twenty Years' Crisis, 1919-1939: An Introduction to the Study of International Relations (Basingstoke and New York: Palgrave, 2001), 49; Koskenniemi, 'International Law as Political Theology', 499. 
responsibility for the worst crimes known to humanity. The selection of Africans exclusively for this dubious honour, while not random, is definitely arbitrary. It is not random because there are real prima facie grounds indicating that persons from the region selected are responsible in some way for the commission of absolutely heinous acts. It is arbitrary, however, because out of a total human population in the billions, the few Africans selected do not have the monopoly on international criminality (not even in Africa) and nor can they be singled out solely as the very worst offenders.

A completely reasonable counter-argument, however, could be made that African states and African people are the most supportive group of the ICC. What is more, the African continent not only has the worst crimes but, most significantly, also has the least infrastructure to deal with these crimes. So is Africa and are Africans the sole focus of international criminal law because of their high enthusiasm for international criminal justice, culpability for international crimes or structural and political weaknesses or some admixture of all three? Article 13 of the Rome Statute provides the trigger mechanism for the ICC's jurisdiction. This Article codifies three separate modes for exercising jurisdiction. The first is the traditional basis of the consent of states. The second is through a referral of the United Nations Security Council by a resolution. ${ }^{135}$ The third provides for an independent prosecutorial power to refer a case. The first and the third are directly derived from state consent and flow from specific Articles of the Rome Statute, 14 and 15 respectively. Plainly because all the modes of triggering jurisdiction have been exhausted exclusively in relation to Africa, it is both culpability and weakness. That is precisely why the selection, while arbitrary, is not random. The inability to prosecute implies weakness but being unwilling to do so constitutes culpability. It would appear then that the pious hope by which punishment will surely follow crime is not perfectly congruent with this reality. Why is it that Africans appear to have the monopoly on the worst crimes that humanity has to offer along with the weakest infrastructure to deal with them? Coincidence? Or is this structural weakness precisely why Africa is targeted rather than any others?

Another objection raised could be that the case often celebrated as heralding the birth, or beginning, of international criminal law (that of Peter von Hagenbach), is, after all, neither from Africa nor of an 
African. ${ }^{136}$ Likewise, the trials after the Second World War of the Nazis, the Imperial Japanese and their Axis partners, were also nothing to do with Africa. Even more so, Italy, which could have provided some accused criminals for their wartime actions in Ethiopia, was not part of these post-war trial processes. ${ }^{137}$ Likewise, the International Criminal Tribunal for the former Yugoslavia, the Extraordinary Criminal Cham: bers for Cambodia and the Special Tribunal for Lebanon also have no obvious bearing on African themes and issues. However, precisely those exceptional and therefore oft-cited cases make the point that now international criminal justice has been normalised by setting up a permanent court, the usual suspects are exclusively African and as yet not even exceptionally non-African. However, given the glacially developing trend whereby the exception gradually becomes the rule, ${ }^{138}$ Africans are only the vanguard for a globalising international criminal justice. Indeed, Giorgio Agamben finds it unsurprising 'that there is a predilection to resort to exemplary punishment in a state of exception'. ${ }^{139}$ The then prosecutor himself said that the court is really helping to establish a new idea in the world with state parties and non-state parties. It will take time. In 30 years, all the world will be a member of the court but in the meantime we are progressing. ${ }^{140}$ The Court thus starts with Africans in order to cut its teeth before promising to sink its talons into bigger prey.

This is the point made again and again that a court that is yet to gain credibility and respect begins with going after the weakest and not necessarily the most criminal. Therefore, it targets Africans not because they are the worst but because they are the weakest. This is supposed somehow to redeem the whole of humanity, thus making Africa the perpetually scapegoated pharmakos that is given up and giving itself up to sacrifice in order to embody the international community through criminal justice. This is neither the time nor the space within which a

135 William Schabas, An Introduction to the International Criminal Court (Cambridge University Press, 2007), 1.

137 Richard Pankhurst, 'Italian Fascist War Crimes in Ethiopia: A History of their Discussion, from the League of Nations to the United Nations (1936-1949)', Northeast African Studies 6.1 (1999), 83-140.

138 Walter Benjamin, Howard Eiland and Michael W. Jennngs, Selected Writings, vol. 4 (Cambridge, Mass.: Belknap Press, 1996), 392.

139 Agamben, Homo Sacer, 23.

140 Walter Menya and Reuters, 'Ocampo Urges Kenya Unity over Reforms', Daily Nation, 1 November 2009, available at http://web.archive.org/liveweb/www.nation.co.ke/News/ / 1056/680212/-/item/1/-/100yn8fz/-/index.html (accessed 14 August 2013). 
comprehensive and satisfactory explanation of such a complex and long standing social phenomenon as the scapegoat mechanism can be elucidated. However, various writers from both inside and outside the traditional international criminal law canon may enrich the discussion and shed some light on the particular concerns raised.

The characterisation 'universal justice' has the international community performing a seemingly external sacrifice (because the accused is taken out of the normal communal relations as a rogue, terrorist, pirate, outlaw, etc.). ${ }^{141}$ On the other hand, the accused's community, which is also the accused community', provides an internal scapegoat to redeem itself. Socially unsanctioned violence violates that most sacred value (sanctity of human life), which requires a sacrifice (trial and sentencing of criminals) that produces a scapegoat ${ }^{142}$ through the punishment of individuals as responsible for future collective breaches of the peace by others. Such ambivalent figures are conceptually similar to persons declared anathema. ${ }^{143}$ The sacrificial economy particularly clarifies inclusion and exclusion mechanisms in the construction and reconstruction of the relationship between the particular (a specific set of facts) and the universal (the general system of law). ${ }^{144}$

\section{Substitutive logic}

The logic underpinning the rhetoric of universal justice through individual criminal responsibility is one where the responsibilities of the whole are substituted for those of a part. To refer once more to the Kenyan case in the then prosecutor's words: the 'whole international community is with the Kenyans; all Kenyans must come together and use the law and justice as a basis for their common future. The common goal is to ensure

${ }^{141}$ Gerry J. Simpson, Great Powers and Outlaw States: Unequal Sovereigns in the International Legal Order (Cambridge University Press, 2004), xi.

142 Gregor Noll, 'The Miracle of Generative Violence? René Girard and the Use of Force in International Law', Leiden Journal of International Law 21.3 (2008): 563; René Girard, The Scapegoat (Baltimore, Md: Johns Hopkins University Press, 1986).

${ }^{143}$ Joseph Gignac, 'Anathema', in Kevin Knight (ed.), The Catholic Encyclopedia (New York: Robert Appleton Company, 1907), available at www.newadvent.org/cathen/ 01455e.htm (accessed 11 April 2011); Henri Hubert and Marcel Mauss, Sacrifice: Its Nature and Function (University of Chicago Press, 1964); Agamben, Homo Sacer; Simpson, Great Powers and Outlaw States, 325.

144. Christopher A. Fox, 'Sacrificial Pasts and Messianic Futures: Religion as a Political Prospect', in René Girard and Giorgio Agamben, Philosophy Social Criticism 33.5 (2007): 63 . 
there is no repeat of violence in the 2012 elections. ${ }^{145}$ This is intended to 'end impunity to prevent future crimes'. ${ }^{146}$ The then prosecutor said that 'Kenya will provide a historic example on how one country chose to address and prevent massive crimes'; furthermore, 'Kenyans, including women, youth, tribal groups, judicial, political, and religious leaders have a role. This is their court. ${ }^{.147}$ As per the then prosecutor's rhetoric, the international community is the community of communities in that it contains all Kenyan communities and individuals.

The then prosecutor's own original contribution to the Kenyan situation was to add exemplification as the means by which to achieve such a preventative approach to violence. He then proceeded to extend its effective reach from Kenya and Kenyans to the wider international community by saying: "Kenya could be an example of how to manage this type of conflict because Kenya had a problem but Kenya stopped the crimes in two months. Now they have to do more to prevent repetition and ensure the next election is an example. ${ }^{148}$ This preventative exemplification to ward off violence thus became a running theme covering not just a specific election in time and space (Kenya in 2012) but also fifteen other elections elsewhere and at different times; moreover, all of them in the future:

The best example is Kenya. Justice for the post-electoral violence in Kenya will ensure a peaceful election in 2012. Additionally, it will send a clear message for the 15 elections to come in the region: violence during electoral times cannot be a tool to retain or to gain power; but it is a sure avenue towards a one-way ticket for prison in The Hague. That is the message we need to send in Kampala. ${ }^{149}$

ICC, 'ICC Prosecutor to Visit Kenya to Meet Victims and Listen to All Kenyans"; press release ICC-OTP-20100504-PR521, 4 May 2010, available at http//reliefweb.int/ report/kenya/icc-prosecutor-visit-kenya-meet-victims-and-listen-all-kenyans (accessed 14 August 2013).

147 Mutinda Mwanzia, 'Ocampo's Action Plans', Standard Digital, 2 April 2010, available at www.standardmedia.co.ke/InsidePage.php? $\mathrm{id}=2000006874 \&$ catid $=4 \& \mathrm{a}=1$ (accessed 11 April 2011).

148 Emma Thomasson, 'Darfur, Kenya Courts to Complement ICC: Prosecutor', Reuters, 30 October 2009, available at http://af.reuters.com/article/topNews/idAFJOE59T0NA20091030 (accessed 11 April 2011).

149 ICC, Mr Luis Moreno-Ocampo, Prosecutor of the International Criminal Court, 18th Diplomatic Briefing, The Hague, 26 April, available at www.icc-cpi.int/NR/rdonlyres/ CA355D60-EC32-467A-8CA6-F7FA93D86C0B/281862/100426LMOspeechdiplomaticbriefing_final.pdf (accessed 11 April 2011). 
Thus, futurity is linked to collective liability to scapegoat the accused by apportioning responsibility for what has not yet occurred and is by no means certain to occur apparently on ultimate behalf of all of humanity. It was as though this is a liturgical exercise that has the then prosecutor effectively intoning: "here judged today is the individual responsible for the communal violence you have suffered (and perpetrated) whom is now punished. Peace be with you for now and ever more.' The recipients of this message of the trial as a spectacle shall, it is hoped, respond affirmatively: 'there, but for toeing the peaceful line, go I'. And if violence were to be no more, peace would surely follow. Once again: 'The results of our investigations in the Kenya situation will be presented to the Judges in December. We are preparing two cases against six individuals. These cases could have a critical role to play in preventing violence in the next election in Kenya and in another fifteen countries of the region. ${ }^{150}$

This exemplary preventative approach is to be achieved by only trying those accused with the greatest responsibility for the worst crimes:

The investigation will focus on those most responsible for the most serious incidents. We will try to conduct an expeditious investigation, aiming to present a sample representative of the crimes committed. We envision at least two cases against one to three persons in each case. We will focus on those who, according to the evidence that will be collected in the course of our independent investigation, are most responsible. ${ }^{151}$

When examining relevant national proceedings of potential cases prosecutorial policy seems to follow the same line of holding a few individuals responsible for the mass by focussing on those who appear to bear the greatest responsibility for the most serious crimes. ${ }^{152}$ This approach is applied in enabling the selection of cases based on 'persons most responsible' or 'those bearing the greatest responsibility' but not making those

150 ICC, Mr Luis Moreno-Ocampo, Prosecutor of the International Criminal Court, 19th Diplomatic Briefing, Statement, The Hague, 3 November 2010, available at www.icc-cpi. int/NR/rdonlyres/F67584DE-F045-45E2-9503-8F4D16B3DEAA/282656/LMO_DiploBriefingspeech_03112011.pdf (accessed 11 April 2011).

151 ICC, Statement: OTP Press Conference on Kenya, Prosecutor Moreno-Ocampo's Statement, 1 April 2010, available at www.icc-cpi.int/en_menus/icc/structure $\% 20$ of $\% 20$ the $\%$ 20 court/office $\% 20$ of $\% 20$ the $\% 20$ prosecutor/reports $\% 20$ and $\% 20$ statements/statement/ Pages/20100401.aspx (accessed 11 April 2011).

152 ICC, Draft Policy Paper on Preliminary Examinations, The Hague, 4 October 2010, available at www.icc-cpi.int/NR/rdonlyres/E278F5A2-A4F9-43D7-83D2-6A2C9CF5D7D7/ 282515/OTP_Draftpolicypaperonpreliminaryexaminations04101.pdf (accessed 11 April 2011). 
standards legal preconditions for admissibility, which would be a hin drance to the then prosecutor. ${ }^{153}$ The Assembly of State Parties to the ICC appears to endorse the view that the ICC has had to take a policy decision to focus prosecutions on 'those bearing the greatest responsibility for the most serious crimes' even though it is not prescribed in the Statute. ${ }^{154}$ However, among professional criminologists there seems to be a broad consensus that the efficacy of punishment in acting as a general deterrent is not the most important factor in lowering crime rates. ${ }^{155}$ Moreover, international criminal trials do little to deter violence or promote reconciliation. ${ }^{156}$

\section{Images and icons of the international community}

Tallgren proposes that perhaps the purpose of international criminal law is less the prevention or suppression of criminality than the establish. ment of symbols, which enable belief in a legitimate international community that can be governed analogously to the nation state. ${ }^{157}$ Tallgren suggests one way to focus differently on international criminal justice is as a continuous remembrance service, akin to divine religious services, which meaningfully targets the questions of life and death, good and evil, as well as the promises of justice, peace and love. ${ }^{158}$ Girard and Agamben have outlined the sacrificial and juridical logics inherent in such an

153 ICC, Appeals Chamber, 'Situation in the Democratic Republic of the Congo' (Prosecutor's document in support of the appeal brought by the prosecution against pre-trial Chamber I's 10 February 2006 decision on the then prosecutor's application for warrants of arrest, Article 58), public redacted version, ICC-01/04, 28 January 2011, available at www.icc-cpi.int/iccdocs/doc/doc1009321.pdf (accessed 11 April 2011).

154 ICC, Second public hearing of the Office of the Prosecutor, NGOs and other Experts, The Hague, 26 September 2006, available at www.icc-cpi.int/iccdocs/otp/OTP_PH2_HGNGO pdf (accessed 14 August 2013).

155 Thomas J. Bernard, Jeffrey B. Snipes and Alexander L. Gerould, Vold's Theoretical Criminology (New York: Oxford University Press, 2010), 20-4.

156 Jack L. Snyder and Leslie Vinjamuri, 'Trials and Errors: Principle and Pragmatism in Strategies of International Justice, International Security 28.3 (2003-4): 5-44; Rosalind Shaw, Lars Waldorf and Pierre Hazan, Localizing Transitional Justice: Interventions and Priorities after Mass Violence (Stanford University Press, 2010), 31-2; Justice Report. 'Trials Have Not Helped Reconciliation, Survey Shows', Balkan Investigative Reporting Network, 11 April 201 1, available at www.justice-report.com/en/articles/trials-have-not helped-reconciliation-survey-shows (accessed 14 August 2013).

157 Tallgren, "The Sensibility and Sense of International Criminal Law', 594-5.

158 Ibid., 593. 
exercise ${ }^{159}$ Lior Barshack, for one, conceives of the court as a social mechanism providing the centre of contemporary civil religion. ${ }^{160}$ Both Girard and Gregor Noll have noted before the proximities of sacrifice to violence and of the trial to the sacrifice. ${ }^{161}$ Secularisation is inadequate as a remedy because it is the shifting (rather than abolition) of concepts from one sphere (religion) to another (e.g. politics or law), consistently with their erstwhile function. ${ }^{162}$ Secularisation can therefore mean the obscured continuation of practices of religious origin, more or less unrecognised or unacknowledged. ${ }^{163}$ Presently, therefore, sacrifice as a social function has shifted register in moving into law through politics from theology.

A esthetics is central to law generally but international law in particular because such central features structuring it, e.g. the aforementioned humanity but also sovereignty, the rule of law, human rights, etc., can only be interacted with indirectly in terms of their positive (actual performance) or negative (perceived lack) manifestation. This means that all of its main principles and concepts are always presented but never present in the real sense. That is to say, they are not to be found as themselves within the material physical realm open to the senses except in and by representation. This is because - it is believed - they are to be found either above or perhaps below but in any event beyond the directly perceptible. Yet they remain in some normative sense the 'truth' behind the representative 'facade'. This briefly passes for the aesthetics of law. The argument indicates that any efforts directed towards interacting with these necessarily transcendent concepts could only be grounded in a secular sacrificial economy. ${ }^{164}$ That is to say, if trial

159. Fiona Jenkins; 'Dialogue in the Aftermath: On Good, Evil and Responsibility after September 11', borderlands ejournal 3.I (2004), available at www.borderlands.net.au/ vol3nol 2004/jenkins_dialogue.htm (accessed 9 October 2009).

160 Lior Barshack, 'The Totemic Authority of the Court', Law and Critique 11 (2000): 301-28.

161. Girard, Violence and the Sacred; Noll, 'The Miracle of Generative Violence?', 563-80.

162: Moreno-Ocampo, Statement, 4 November 2009, 77.

163 Karl Lowith, Meaning in History: The Theological Implications of the Philosophy of History (University of Chicago Press, 1949); Ernst H. Kantorowicz, The King's Two Bodies. A Study in Mediaeval Political Theology (Princeton. University Press, 1997); Carl Schmit, Political Theology: Four Chapters on the Concept of Sovereignty (University of Chicago Press, 2005); Carl Schmitt, Political Theology II: The Myth of Closure of any Political Theology (Cambridge: Polity Press, 2008); Michael A. Gillespie, The Theological Orgins of Modernity (University of Chicago Press, 2008).

164 Peter Goodrich, Languages of Law: From Logics of Memory to Nomadic Masks (London: Weidenfeld and Nicolson, 1990); Thanos Zartaloudis, Giorgio Agamben: Power, Law and the Uses of Criticism (New York: Routledge, 2010), 16. 
works by displacing social and individual perceptions of guilt onto the accused (who is selected for his or her sins but not only for his or her sins is he or she punished but also those of others), then it displays an irrepressible sacrificial economy.

\section{What is a sacrifice? core and collateral effects and affects}

What would happen if a would-be sacrificial victim were given a voice? There are three examples of human sacrifice documented in the Christian Bible. To start with probably the least known, that of Jephthah of his daughter (we are not even told her name), who was sacrificed in exchange for victory in a war over the Ammonites by her father. Apparently, although unhappy, she accepted her fate quietly, and was duly sacrificed. ${ }^{165}$ The case of Abraham and his first-born son Isaac is probably more familiar than the first. Abraham was instructed to sacrifice Isaac to prove his piety towards God. While on the way to the altar when the unsuspecting son innocently inquired as to the whereabouts of the sacrificial lamb, he received the response that God would provide. Indeed, God did, but only after Abraham was about to slit his own son's throat as an offering. ${ }^{166}$ We therefore are not told what view Isaac would have had of the proceedings had he been fully appraised of them beforehand. The last example is probably the most well-known and influential, where Jesus Christ, simultaneously both God and man, was given over in sacrifice by God his father to humanity in order to redeem that humanity. ${ }^{167}$ Jesus, while fully aware of and initially willing to go along with the sacrificial elements of his death, nevertheless expressed some reluctance that was subsequently overcome to accept it. ${ }^{168}$ More to the point, the last is a profoundly influential sacrifice because its daily ritual re-enactment and reaffirmation does not require an actual death but only simulates the original foundational sacrifice of Christ's crucifixion. One does not have to be a Christian believer to appreciate the value of a simulated death underpinning such a nevertheless efficacious sacrifice.

A sacrifice is therefore not a simple word at all. It requires at a bare minimum three elements: the person, animal or object offered up for sacrifice itself; the individual or community making the sacrifice; and the immaterial but representable idea, being or deity to whom the sacrifice is

165 Robert P. Carroll and Stephen Prickett (eds.), The Bible: Authorized King James Version (New York: Oxford University Press, 2008), 310-12.

166 Ibid., 23-4. ${ }^{167}$ Ibid., 39. ${ }^{168}$ Ibid., 41. 
being made. ${ }^{169}$ The relationship between these various elements is an additional layer of complexity. The sacrifice and the person making the sacrifice must be somehow connected without necessarily being identical. The relationship between the person making the sacrifice and the entity to which the sacrifice is addressed can only be representative. That is, both indirect and uncertain. This interaction is therefore not one of direct exchange or a trading of favours, as it were, but more one of supplication; which if performed in the ritually correct manner promises to bring about the desired response.

Sacrifice is a transcendental concept, which as such is a necessary condition of possibility for the international criminal justice system. As seen above, the phenomenon of redemptive sacrifice is not new or even new in its theological aspects to international law. ${ }^{170}$ The elements of sacrifice most relevant to international criminal justice are redemption, atonement, expiation and purification. Redemption connotes deliverance from sin and damination, including by atonement or expiation. Expiation is a means by which redress (for a crime or offence) is made by an accused through, for instance, punishment. Atonement connotes restoration or reconciliation of friendly relations by reparation of wrong or injury through making amends or providing satisfaction and, in that way, purifies society of the pollution of the harm done.

By empathising with sacrificial victims it is imperative to note that a sacrifice, by its very nature, is just a performative exercise that is never literally true but only either efficaciously or inefficaciously performed. There can never be any real sacrifices because it is all about figuratively indirect and therefore necessarily uncertain substitutions. They are all simulations, ritualised exercises to bind society through compelling spectacle. As a virtual activity, therefore, they do not need the collateral real and repetitive spilling of blood, as it were, to impress their core moral or political lessons upon pious or impious onlookers. The affective states that trials are intended to produce on the audience are not directly linked to their punitive effects on the accused.

169 Henri Hubert and Marcel Mauss, Sacrifice: Its Nature and Function (University of Chicago Press, 1964).

70 Jennifer Beard, "Understanding International Development Programs as a Modern Phenomenon of Early and Medieval Christian Theology', Australian Feminist Law loumal 18 (2003): 27-54; Judith Gbrich, 'Secrets of the Fetish in International Law's Messianism', in Anne Orford (ed.), International Law and its 'Others' (New York: Cambridge University Press, 2006), 197-220; Anne Orford, 'Trade, Human Rights and the Economy of Sacrifice', ibid., 156-96. 


\section{Social catharsis}

Richard Dawkins's notion of memetic transmission encapsulates nicely the cultural shifting of the trial-as-sacrifice by explaining how the descent (if not the origin) of law and the legal system from the sacred could occur. ${ }^{171}$ The trial can be seen in the form of a morality tale rippling across space and time through a series of memes; peace is good and beneficial while war is bad and attended with prohibitive cost. The trial is subsequently installed as an archive and repository of communal values. By linking prosecution of the accused to achieving peace, the court makes the virtual sacrifice paradigmatic of the international criminal trial. The trial-as-sacrifice through the scapegoated pharmakos provides both social bonding and the binding of violence. This is how international criminal trials build the international community up through instrumentalising empathy or identifying the self with the other in the dock, which enables formation of society via outlawry, etc. where the excluded provides the boundary for inclusion. ${ }^{172}$

To summarise the line of argument pursued to this point, the two limbs of the central ethical problem identified - the ambivalence of justice (by making an example of one from the past to others in the future) and ambiguity of universality (exclusive focus on Africa) - are linked by the pharmakos mechanism (explained below) through preventative approaches to legal justice. In the Kenyan case study chosen, both the Kenyans and the then prosecutor share a common faith in the value of this preventatively sacrificial economy in hopefully eradicating violence. If the Kenyans initiated the process, then the ICC prosecutor continued and extended it. Even so, as we will see below, defence counsel note it with alarm and, likewise, the then prosecutor actually charges some accused with practising it themselves. Therefore, in international criminal justice as social catharsis, the international community is making the sacrifice, Africans (who both belong to and are excluded from the international community) are the sacrifice, and the entity they are sacrificed to is a 'justice' that is never present but is only ever presented.

The paradox of individual criminal responsibility for mass communal violence has led defence counsel to go on record with misgivings about this approach on the basis that it is liable to generate scapegoats:

Richard Dawkins, The Selfish Gene, 30th amniversary edn (New York: Oxford University Press, 2006), 192.

172 Simpson, Great Powers and Outlaw States, xi. 
When it comes to crimes in Ituri, those who are the most powerful are spared. Thomas Lubanga is charged in place of those who should have been prosecuted, and so the accused is placed in an unacceptable situation. The International Criminal Court is put before an immense danger, a fearsome danger, because the International Criminal Court cannot prosecute all of the suspects. And because it can never prosecute all of the suspects, international criminal justice must necessarily face the temptation to convict by proxy those who are absent. The danger is tremendous, because beyond the prosecution of an individual, an attempt is made to prosecute a criminal phenomenon which is far greater than him. The accused then becomes or risks becoming a scapegoat. ${ }^{1 / 3}$

The defence counsel further expanded upon the idea portraying the accused as a scapegoat:

As regards scapegoats, we must ensure that the concept of individual criminal responsibility is applied. Only this vigilance on the principles and on the evidence can enable the International Criminal Court to meet the challenges of justice, the human and symbolic challenges inherent in any trial before it; and that double vigilance is all the more important, your Honours, in that in bringing before you to be judged Thomas Lubanga, and bringing before you Thomas Lubanga to be judged in the place of those who bear the greatest responsibility for the crimes committed in Ituri, one is seeking to have you play a role which is not yours, one which cannot be yours, one which must not be yours. ${ }^{174}$

The spectre of the scapegoat also crops up in yet another case on this occasion, introduced by the prosecution this time, explicitly linked to the notion of sacrifice and as evidence to prove knowledge of serious crimes against a civilian population by the accused:

Witness 45 provides further details in regard to the trials. He states that none of the soldiers served a full prison sentence. The witness further states that Jean-Pierre Bemba reassured the ones tried that, and I quote: 'It was done for outside people, and after that they would be released.'

Approximately one month following their convictions, Jean-Pierre Bemba granted them amnesty and they were reintegrated into the MLC force. In referring to the case of Commander Ngalimo, who was the MLC commander, your Honours, in the Mambasa sector, the witness states that he

173 ICC, International Criminal Court, Trial Chamber I, Situation in the Democratic Republic of Congo - Case ICC-01/04-01/06. Hearing - Open Session, Tuesday, 27 January 2009, available at www.icc-cpi.int/iccdocs/doc/doc623848.pdf (accessed 11 April $2011), 31$.

174 Ibid, 33 . 
was found guilty for the murders - for murders and pillaging and sentenced to five years' imprisonment. And he further states that when Ngalimo complained of having been sacrificed and being used as a scapegoat, Jean-Pierre Bemba sent someone to reassure and promise him that he would be released soon thereafter. Only one month later, Ngalimo was granted amnesty and received a promotion to the rank of a colonel. ${ }^{175}$

In keeping with the perception of a redemptive sacrificial econony $a$ former Kenyan Member of Parliament, Ms Jayne Kihara, of whom it is alleged that she financed and bought machetes for gangs involved in attacks, chimed into the debate and referred to herself as a 'sacrificial lamb ${ }^{176}$ Sacrifice therefore meaningfully links even primarily oral and primarily literary communities. The example, which appears in such different guises as precedent, or case study, even acts as a morality tale linking literal and figurative statements. It is therefore clear that potential accused, the then prosecutor and defence counsel are all alive to the idea and dangers of using legal processes to generate scapegoats in a sacrificial context. To summarise the workings of the iconography envisaged, politically motivated violence in Kenya, although unique, once dealt with serves as an exemplary case to influence in future the international community generally and at least fifteen other African countries in particular. This renders any convicted individuals responsible not onl for their own past actions but also for the potential actions of others in the future. On the face of it, this is a departure from the norm, because past rules guiding present actions provide the usual basis for the criminal law in which each person is individually responsible for wrongs already committed by them and not for the wrongs of others that are yet to be committed and indeed may never be committed.

The afflicted (and afflicting) communities are a singled out part of the international community and therefore the scapegoat is simultaneously from both local and global communities; this is why the useful paradox of sacrality/homo sacer/scapegoat is relevant to explain how a being can be inside and outside at the same time. According to Jacques Derrida, the

175 ICC, Confirmation of Charges Hearing (Open Session), International Criminal Court Pre-Trial Chamber III, Situation in the Central African Republic - case ICC-01/05 01/08. Confirmation of Charges Hearing - Open Session, 14 January 2009, available at wwwicc cpi.int/iccdocs/doc/doc618933.pdf (accessed 11 April 2011), 106.

176 Emeka-Mayaka Gekara, 'Former MP Pleads Innocence against War Crimes, Daily' Nation (4 December 2009), available at www.nation.co.ke/News/politics//1064) 817672/-/wu6ptcz/-/index.html (accessed 11 April 2011). 
scapegoat or pharmakos is a being that simultaneously belongs and does not belong to society. 177 . This coincidence between outsider and insider makes the scapegoat more easily amenable to sacrifice for communal atonement or expiation. They belong to the community enough to be associated with it but are just vulnerable enough within it to be picked on as the victims of sacrifice. The pharmakos therefore exemplifies a vehicle through which a social body figuratively expels evil, harm or wrongdoing from itself as a purificatory process. The scapegoat is paradoxical because it is the border between inside and outside, making it both and neither. In this way, society constitutes and reconstitutes both its make up and its moral values.

Frazer, in his magisterial ethnographic study of the scapegoat, meticulousiy documents examples from all over the world, demonstrating the theory and practice behind how ritually to transfer the guilt of a whole people onto an individual human, animal or object. ${ }^{178}$ If we think of the human as a hyphen that connects god to animal, the dividing line between the two necessarily passes through the human that is a sort of divine animal. ${ }^{179}$ According to Frazer, 'when a nation becomes civilized, if it does not drop human sacrifices altogether, it at least selects as victims only such wretches as would be put to death at any rate. Thus the killing of a god may be confounded with the execution of a criminal. ${ }^{3180}$ Further: a common and successful device is to consummate the sacrifice on the person of a malefactor, whose death at the altar or elsewhere is little likely to excite pity or indignation, since it partakes of the character of a punishment, and people recognize that if the miscreant had not been dealt with by the priest, it would have been needful in the public interest to hand him over to the executioner'. ${ }^{181}$

The ambivalence and ambiguity outlined make it possible to draw beth distinctions (within universality and humanity) and comparisons (between separate cases both actual and potential) where there otherwise was none. Describing the exemplification process is therefore a foray into representations in the realm of law, i.e. legal aestheticisation. Agamben states that glory' is 'the uncertain zone in which acclamations,

17. Jacques Derrida, Dissemination (Chicago University Press, 1981), 130-4.

178 ames G. Frazer and Robert Fraser, The Golden Bough: A Study in Magic and Religion (Oxford University Press, 2009), 557.

177. Tacques Derrida and Geoffrey Bennington, The Beast and the Sovereign: Seminars of Iacques Derrida (University of Chicago Press, 2009), 13; Giorgio Agamben, The Open: Uan and Animal (Stanford University Press, 2004), 37.

186 Frazer and Fraser, The Golden Bough, 588-9. 181 Ibid., 660. 
ceremonies, liturgies, and insignia operate. ${ }^{182}$ In being a cautionary example to others, the accused is a peace sacrifice in a literary, or figurative, or iconographic sense. This 'sacrifice for peace' element gives the entire international criminal trial a decidedly quasi-religious aspect with the trial standing in as a secular sacrifice that casts the accused as a social scapegoat for the preservation of peace. There are at least two challenges of representation here. One might be how to ground the real and immediate jurisdiction of the court over perpetually potential cases. The other is attendant upon portraying Africa as a terrain of, and Africans as a cipher for, all the worst of humanity's ills. The mysterious link between the two is the scapegoat/pharmakos mechanism already encountered in several instances above.

Although sacrifice links simultaneously both violence and trial in international criminal justice, nothing has as yet been written on it as being explanatory of Africa's peculiar position within it. This chapter noted the sacrificial economy of law not merely to note or even applaud its potentials and redemptive capacity, but it is also a directed critique suggesting that international criminal justice is all and only about affects and icons; that such a sacrificial economy of law could potentially be organised without any actual victims. One possible way towards this is to shift emphasis from law enforcement, aimed at redressing breaches once they occur, to law fulfilment, addressed at achieving the promise of the law before it is breached. ${ }^{183}$ All we should unflinchingly acknowledge is the anarchic core of international justice where violence is both benediction and malediction simultaneously. Consequently short-term interventionist and, in the end, ineffectual responses to political violence should be abandoned. The study began by attempting a partial demystification of basic concepts in the panoply of international criminal justice, not in order to advocate abolishing or abandoning them immediately, but to suggest finally positive ethical transformations in their use in order to align those practices more closely to the aims of apportioning responsibility equitably, promoting reconciliation in affected communities, and encouraging remorse in convicted offenders in order to prevent the recurrence of political violence. This would hopefully bind the sacrificial logic, rhetoric and aesthetic of international criminal justice to an ethic of empathy that strives to be truly universal and truly just.

182 Agamben, The Kingdom and the Glory, 188.

183 Ibid.; Agamben, Language and Death. 